\title{
Optimizing hydropower development and ecosystem services in the Kafue River, Zambia
}

Ian G. Cowx ${ }^{1 \#}$, Alphart Lungu² \& Mainza Kalonga ${ }^{3}$

1: Hull International Fisheries Institute, University of Hull, Hull HU67RX, UK

2: c/o UNDP Zambia, UN House, Alick Nkhata Road, O)Box 31966 Lusaka 10101 Zambia [email: alphartlungu@gmail.com]

3: Department of Fisheries, Chilanga near Lusaka, Zambia [mukanzubo@gmail.com]

Current address P.O Box 360130 - Kafue, Zambia.

The published version of this article is available at https://doi.org/10.1071/mf18132

Running title: Optimizing hydropower with ecosystem services

\# Corresponding author. Prof Ian G Cowx, Hull International Fisheries Institute, University of Hull, Hull HU67RX, UK. email: i.g.cowx@hull.ac.uk 


\begin{abstract}
Fisheries are an important resource in Zambia, but are experiencing overexploitation and are under increasing pressure from external development activities that are compromising river ecosystem services and functioning. One such system is the Kafue Flats floodplain, which is under threat from hydropower development. This paper reviews the impact of potential hydropower development on the Kafue Flats floodplain and explores mechanisms to optimise the expansion of hydropower whilst maintain the ecosystem functioning and services the floodplain delivers.

Since completion of the Kafue Gorge and Itezhi-tezhi dams, seasonal fluctuations in the height and extent of flooding have been suppressed. This situation is likely to get worse with the proposed incorporation of a hydropower scheme into Itezhi-tezhi dam, which will operate under a hydropeaking regime. This will have major ramifications for the fish communities and ecosystem functioning and likely result in the demise of the fishery along with destruction of the wetlands and associated wildlife. To redress the problem it is recommended that an environmental flows study is conducted, as initiated by World Wildlife Fund, to protect the existing ecosystem services provision and optimise hydropower development, thus ensuring sustainability of the aquatic resources of the Kafue Flats for future generations.
\end{abstract}

Keywords: fisheries, floodplain ecology, flow regulation, livelihoods, SDGs, wildlife. 


\section{Introduction}

Zambia enjoys an abundance of water resources in the form of lakes, streams, rivers, floodplains and swamps, covering approximately $145,200 \mathrm{~km}^{2}$ of water area. The country is drained by the Congo River Basin in the north and Zambezi River Basin in the south. This provides a wealth of fisheries resources, and the sector is third in terms of contribution to GDP after mining and agriculture. Catches fluctuated around 50-60,000 t in the early 2000 s, but have increased towards 80,000 t in recent years (Department of Fisheries, 2017 unpublished report). This is largely due to increased catches from lakes, especially Kariba, and aquaculture production, the latter of which accounted for more than $22,700 \mathrm{t}$ in 2015 and continues to expand.

Within Zambia, fishing is an important livelihood (employment, earnings and food and nutrition security) with an estimated 300,000 people from a population of approximately 13 million (CSO, 2011) engaged in the sector (Musumali et al., 2010). Rural communities in particular, derive much of their income (most of them poor and food insecure populations) directly from fishing, or indirectly as traders, processors and provision of other services (boat building and repair, net manufacturing, and transportation). Fisheries play a vital role in contributing to national food security (fish provide about $30 \%$ of the animal protein intake in Zambia: Zambia Country Profile, FAO, http://www.fao.org/fishery/countrysector/FI-CP_ZM/en) and employment (Musumali et al., 2010). The bulk of fish is distributed mainly through informal channels by private and individual traders, many of them women. Furthermore, the sector, particularly due to its mainly rural setting and open access, makes a contribution to rural welfare in terms of livelihoods and provision of affordable protein.

The sector is, however, experiencing resource overexploitation, and socio-economic, institutional and management problems that directly affect fish stocks and fish production, evident from declining catch per unit effort as a result of intense fishing pressure and use of unsustainable fishing methods. In addition, the sector is under increasing pressure from external development activities that are compromising river ecosystem services and functioning. Consequently, the fisheries sector is increasing unable to supply fish and fish products to low-income groups, for whom it represents an important and often only affordable source of animal protein and micronutrients.

One such system that is under considerable pressure is the Kafue Flats floodplain fishery, which historically yielded between 6000 and 8000 tonnes of fish per year (Department of Fisheries, 2017 unpublished report). The area is subject to considerable development because of its close proximity of Lusaka, the capital of Zambia, and in particular from hydropower development, including the proposal to adapt one dam (Itezhi-tezhi) from storage to 
hydropower production, which will potentially alter the flooding regime that the ecosystem is highly dependent on to deliver services for the local and regional peoples.

This paper reviews the impacts of proposed hydropower development on the Kafue Flats floodplain and explores mechanisms to optimise the expansion of hydropower in the catchment whilst maintaining ecosystem functioning and the services it delivers.

\section{Description of the Kafue Flats}

The Kafue River is a major sub-catchment of the Zambezi River (Figure 1), lying completely within Zambia. With an area of $156,995 \mathrm{~km}^{2}$, the basin accounts for about $20 \%$ of the total land area of the country. The area of interest is the Kafue Flats floodplain situated mainly in the Southern Province of Zambia between latitudes $15^{\circ} 20^{\prime}-15^{\circ} 55^{\prime} \mathrm{S}$ and longitudes $26^{\circ}-28^{\circ} \mathrm{E}$ (Figure 1). The floodplain is a broad alluvial plain $440 \mathrm{~km}$ long and $60 \mathrm{~km}$ wide, covering an area of approximately $6500 \mathrm{~km}^{2}$ between two dams - Itezhi-tezhi and Kafue Gorge. Itzezhi-tezhi dam is a storage dam for the Kafue Gorge hydropower dam facility. As a result of its shallow gradient (6 $\mathrm{m}$ from Itezhi-tezhi to the impounding reservoir surface elevation of Kafue Gorge), the Flats are characterised by floodplain wetlands and swamps, but the region also has seven large lagoons, namely Lukwato, Namwala, Kabulungwe, Chunga, Luwato, Chanyanya and Chansi, which are considered potential fish breeding areas based on the size and number of fish caught. The floodplain supports a wetland ecosystem of exceptional productivity because of periodic inundation, although the extent and duration has changed since completion of Itezhitezhi dam in 1978. Prior to construction of Itezhi-tezhi dam, an area of between 22 and $60 \mathrm{~km}$ from the river channel was flooded annually, but this has been reduced to 10 to $15 \mathrm{~km}$ in good rainy seasons, and has been subject to further modification in recent years. Most of the shoreline, lagoons or swampy areas are characterized by high presence of hippo grass (Vossia) mixed with Polygonum, bull rushes (Typha), matete reed (Phragmites) and papyrus (Cyperus papyrus). 


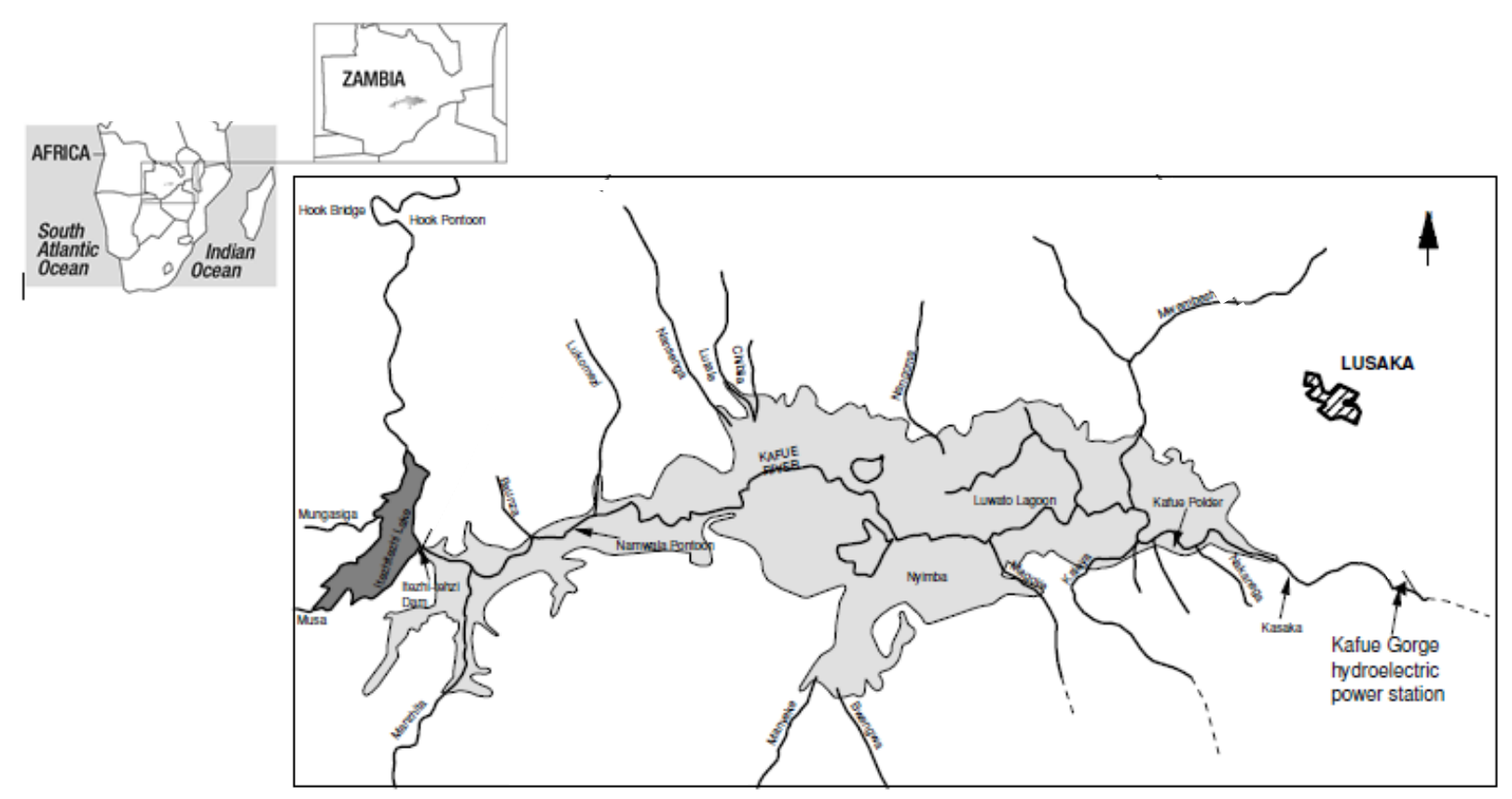

Figure 1. Outline of Kafue Flats floodplain. (Source: modified from WWF-Zambia, 2006) Light grey shading shows extent of floodplain. On the western end is Itezhi-tezhi reservoir (dark grey shading) and at the eastern end is Kafue Gorge Hydroelectric Dam.

The movement of air masses associated with the Inter-Tropical Convergence Zone largely controls the climate of the Kafue catchment. The main rainfall season occurs from November to March and is associated with peak flooding on the Flats, but this has now been modified by the hydropower development in the catchment. Maximum flood under natural conditions first occurs in the western part of the Flats in February/March and then moves east to peak in the Kafue Gorge area in April/May. Annual variation in the area flooded ranges from a minimum of about $300 \mathrm{~km}^{2}$ to in excess of $5000 \mathrm{~km}^{2}$, depending on rainfall events in the particular year. The extent of the floodplain inundated by floodwaters and the annual cycle of flooding and drought exert a profound effect on fish productivity in the Kafue flats (Chapman et al., 1971). Aquatic grasses and other vegetation grow rapidly following the advent of the floods during the rainy season and most fish species reproduce around this period, so the resultant young fish have access to food and shelter.

The Flats are one of the most biologically diverse ecosystems in Zambia (WWF, 2006). The complex pattern of lagoons, disconnected river channels, marshes and floodplain grassland provides habitat for a high diversity of birds and animals, including rare and endemic species, most notably the Kafue lechwe (Kobus leche), an antelope adapted to life on flooded grasslands and wetlands. Over 400 bird species have been documented, including 125 waterbirds and the endangered wattled crane. The Kafue Flats support large numbers of grazing mammals, including hippopotamus, zebra, sitatunga and buffalo, and predators such as cheetah and wild dog. The number of lechwe has declined considerably from in excess of 
90,000 in the 1970 s to less than 30,000 in recent years (Shanungu, Kaumba \& Beilfuss 2015.). Up to 77 species of fish have been recorded in the Kafue system, of which about 20 species are commercially important, particularly Oreochromis andersonii, O. macrochir, Coptodon rendalli, Tilapia sparrmanii, Oreochromis niloticus, Schilbe intermedius, Clarias gariepinus and Clarias ngamensis (Chabwela 1992). It should be noted that several of these species (greenhead tilapia (Oreochromis macrochir) and Nile tilapia (Oreochromis niloticus)) are not indigenous to the Kafue Flats and have probably escaped from fish farms. (Schwanck 1995).

\section{Methods}

To understand the interactions between hydropower development and ecosystem functioning and services delivery in the Kafue floodplain, information was collated from Zambian Ministries and associated line agencies, reports and the grey literature.

Information were collected from the primary and grey literature on: the ecology of the major exploited biota; current status and management of the fish stocks, including access rights and management measures (effort, gears, closed seasons and areas); status of the aquatic ecosystem, including habitat degradation and pollution; utilisation of wetlands and riparian zones (wildlife, agriculture and forestry practices); hydropower development. Consultations were also carried with the Department of Fisheries, external agencies that have a potential impact on the fisheries, and key fishing communities and stakeholders to ensure their participation in the development of the management process. These included the Ministry of Environment, Tourism and Natural Resources (METNR), Zambia Wildlife Authority (ZAWA), Zesco (a parastatal managing both the Kafue Gorge and Itezhi-tezhi dams and as such is responsible for all flow releases) fish farms, Zambia Sugar Company (ZSC), WWF, WorldFish, Ministry of Agriculture and Cooperatives (MACO), The Environmental Council of Zambia, Ministry of Energy and Water Development (MEWD), Department of Water Affairs (DWA) and Ministry of Lands.

The information generated from the review and consultations was used to identify the issues impacting on the sustainability of the fisheries and aquatic resources, conservation of aquatic diversity and management of the environment. Options for management of the fisheries and aquatic resources and maintenance of the ecosystem services were explored, particularly with reference to optimising the development of hydropower in the Kafue river basin. 


\section{Results}

\section{Use of natural resources}

The Kafue Flats floodplain is a vital resource in southern Zambia for wildlife, fishing, recession agriculture, dry season cattle grazing, sugar cane farming, aquaculture, mining and hydroelectric power production. Its close proximity to Lusaka means that production and outputs from the region has a ready market. Some 800,000 people live on or in the vicinity of the Kafue Flats, thus the Kafue Flats floodplain plays an important role in the Zambian economy (WWF 2006). These include many rural poor people who are directly dependent on the services delivered by the aquatic resources in the Kafue Flats for their food security and livelihoods.

The Kafue fishery makes an important contribution to national fish production and supply (approximately $8 \%$ of capture fisheries). Fishing represents a source of nutrition and sustains a variety of livelihoods ranging from those who catch the fish to those who process and trade the catch (World Fish Center, 2004). The floodplain fishery is one of the most productive and important sources of fish supply to Lusaka. Production appears to have fluctuated over a 7-year cycle between about 3000 and 10,000 $\mathrm{t} \mathrm{yr}^{-1}$ before closure of Itezhi-tezhi in 1978, but has stabilised around $6000 \mathrm{t} \mathrm{yr}^{-1}$ in recent years, with an additional 2000-2500 $\mathrm{t} \mathrm{yr}^{-1}$ produced from Itezhi-tezhi reservoir (Figure 2). The fishery is exclusively artisanal but the scale of the fishing effort is considerable and increasing (Nyimbli, 2006). These catch statistics are, however, considered to be gross underestimates and appear to be based on fish passing through formal markets. The stable catches over such a long time period suggest the catch assessment surveys, linked to the lack of regular frame surveys and investment in reporting, are not sufficiently rigorous to provide robust data. The landings also do not take account of household consumption, bartering and fish that pass through informal markets to places likely DR Congo. There is a need to carry out household surveys in the region (Fluet-Chouinard et al., 2018), in addition to supporting adequately resourced catch assessment surveys, to assess fully the contribution of the fishery (and others in Zambia) to food production. 


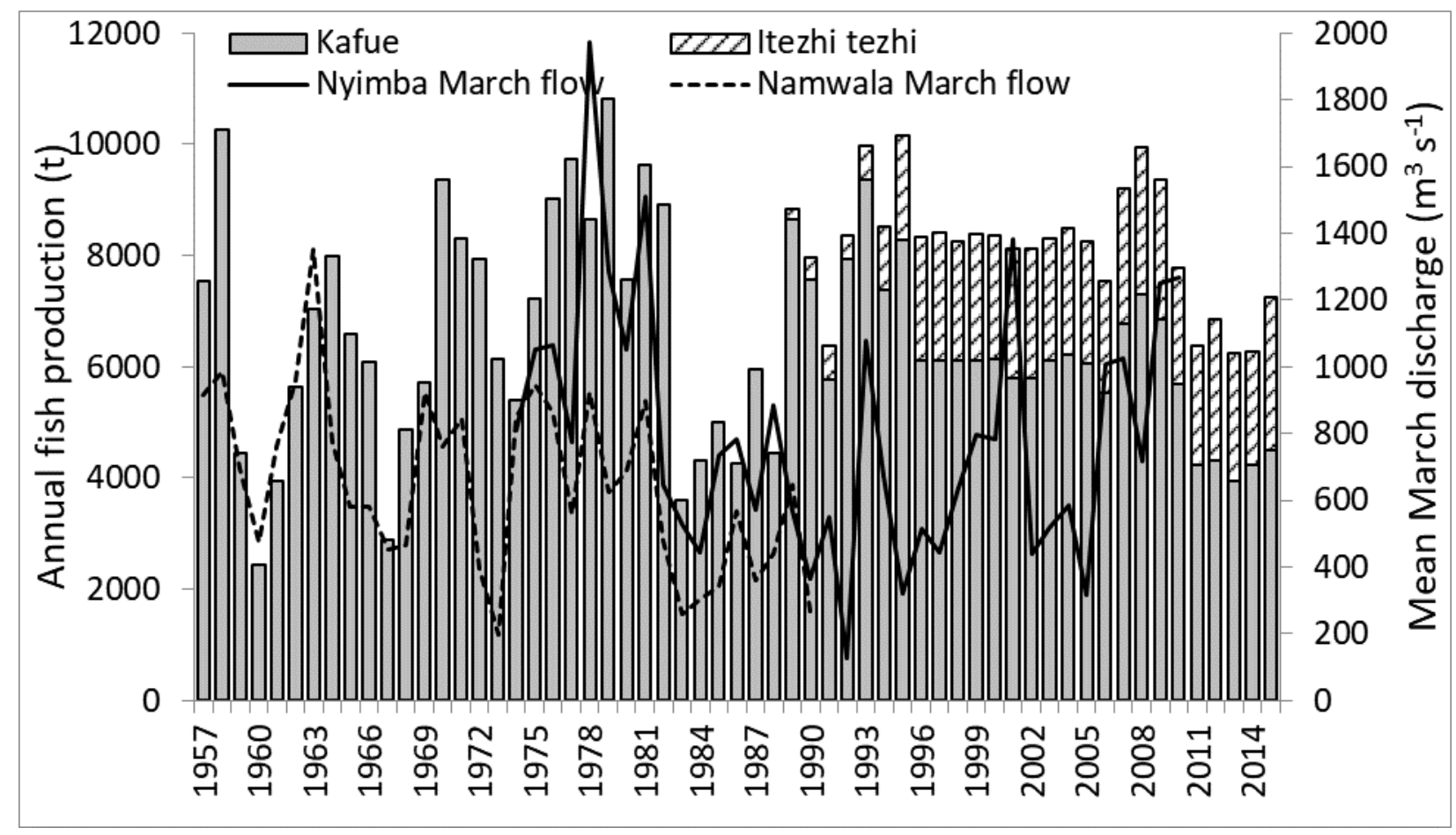

Figure 2. Trends in total fish catches (t) from the Kafue Flats and relationship with mean March discharge at Itezhi-tezhi.

Dudley \& Scully (1980) noted a change in the species composition of fish catches in the Kafue Flats following the commissioning of Itezhi-tezhi dam. Consultation with fishing communities confirmed this change, but they also indicated a more recent shift towards Nile tilapia and preponderance of red-claw crayfish in the catches, and more recently there has been a shift to catches dominated by Brycinus lateralis and Tilapia sparrmanii as a result of the proliferation of small meshed $(2.5 \mathrm{~cm}$ ) nets (D. Tweddle pers. comm.). Unfortunately, the catch assessment surveys do not collect consistent information on species composition of catches. However, evidence of changes in the fish species composition is available from the experimental gillnet studies carried out by the DoF research station in Chunga Lagoon. Catches in $50-125 \mathrm{~mm}$ gillnets have changed since 1980, as illustrated by a Multi-Dimensional Scaling based on the Bray Curtis similarity index, where three distinct periods with significantly different species composition were discriminated (Figure 3). There has been a shift from a riverine species dominated community in the early 1980s to eurytopic species dominated community in the 1990s, and finally to a lacustrine species dominated community in recent years. The experimental gillnetting fails to account for the predominance of Nile tilapia in the commercial catches but this is possibly because the nets are set in open water rather than closer to the littoral zone where Nile tilapia tend to aggregate.

One further observation from the catch statistics is the apparent coupling of catch with the annual flooding regime (Figure 2). Prior to completion of Itezhi-tezhi, catch appeared to be linked to the intensity of flooding in March, but this relation has been disrupted following flow 
regulation. Care must be taken when interpreting these data because the catch data do not account for change in fishing effort over time, which will potentially override any environmental driver of fish production.

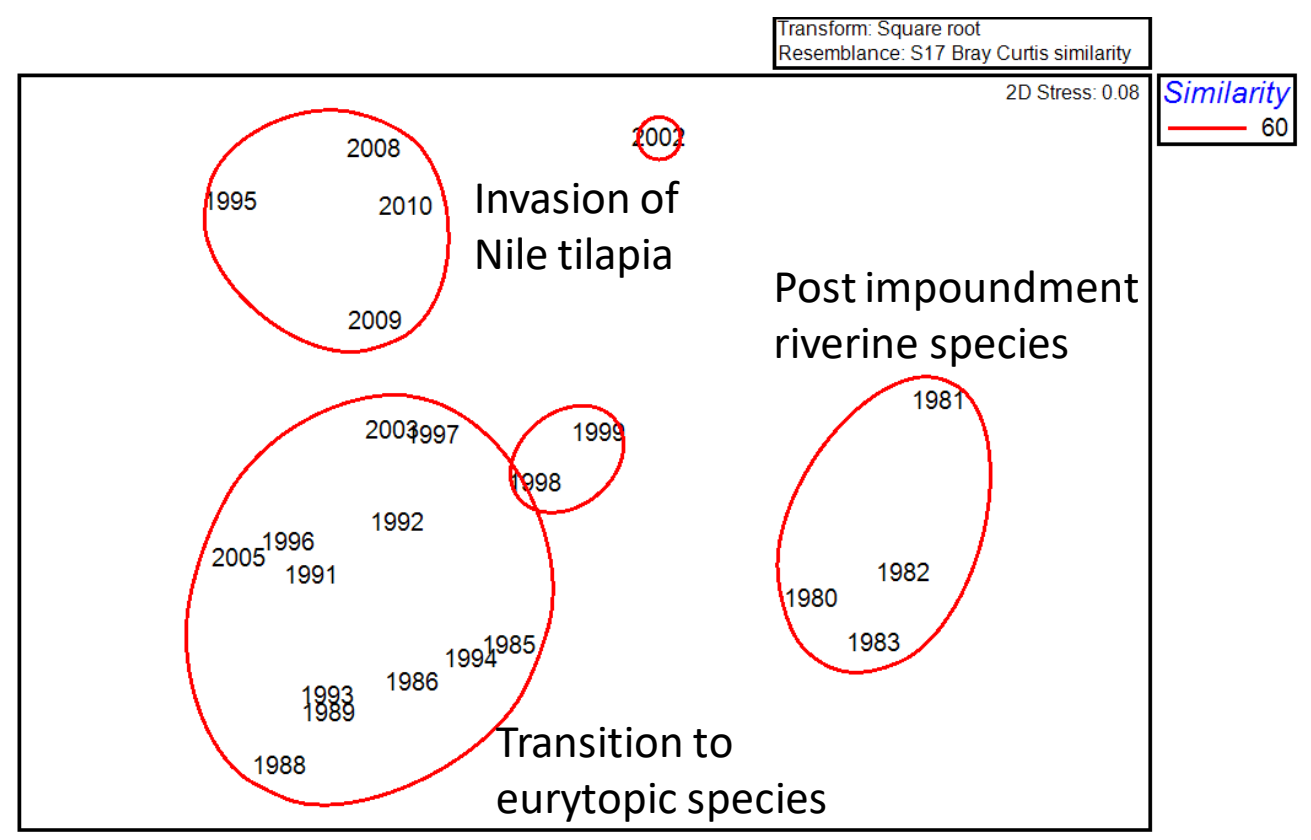

Figure 3. MDS plot of species change in gill net catches from Kafue Flats

Seyam et al. (2001) estimated the value of the Kafue Flats fishery to be around US $\$ 13$ million based on first sale value. If extrapolated to account for the informal markets and domestic consumption, this value is likely to increase markedly. However, if the full economic value (to include equipment and services, boat building, transportation services and provision of ice and other processing costs) is derived, the contribution of these fisheries to incomes and livelihoods, particularly of the rural poor communities that inhabit the Kafue Flats, will potentially be considerable (based on similar analyses in rural fisheries; e.g. Bene et al. 2010, 2016).

The Kafue Flats have traditionally been used for a variety of both commercial and subsistence activities beyond fisheries. Cattle grazing is a major commercial activity, with some $300,000+$ cattle being grazed during the dry season. The main livestock maintained by fishing villages is poultry, but recession agriculture (maize, ground nuts and cassava; source CSO \& DoF 2007) is practiced by fishing villages during the dry season. Women are engaged in basket and matmaking woven from reeds and papyrus at a subsistence level, but there is little use of timber and other forestry products. Although technically illegal, hunting (e.g. of lechwe) provides a source of protein and income for local people (Chansa \& Kampamba 2010). There is considerable commercial farming on the Kafue Flats, primarily for sugar and wheat. The Flats is the major sugar producing area for Zambia for both local use and export, contributing an estimated ZAR 4billion to the economy in 2012/13, equivalent to about $2 \%$ of Zambia's GDP. 
Wildlife tourism is prevalent in the Kafue Flats. Two national parks and associated tourist facilities, notably Lochnivar and Blue Lagoon (Figure 1), were established in the early 1970s, but these have failed to reach their potential and are poorly visited. These parks, and increasing private land ownership, mainly sugar estates, have disrupted traditional cattle ranching and reduced access to water and grazing land.

Fish farming has developed rapidly in the Kafue Flats in recent years (Kafue Fisheries, Nakambala Sugar Estates and Savannah), mainly because of increased demand for high quality fish products in Lusaka, but also the improved availability of preparatory fish feeds.

\section{Water resource development}

Several institutions and stakeholders are directly involved in the use and management of water resources associated with the Kafue Flats. The Water Development Board of the MEWD manages water rights, and issues abstractions licenses for the Kafue River. The current water allocation system fixes an upper limit on the amount of water that each user with water rights can extract from the river on any one day. Additional restrictions on abstractions may also be stipulated in the license. Zesco is responsible for managing the water resources, and hence flow regulation patterns, at both the Kafue Gorge and Itezhi-tezhi dams. Zesco has the right to abstract up to $215 \mathrm{~m}^{3} \mathrm{~s}^{-1}$ for the purposes of energy generation at Kafue Gorge. Within this water right there is a requirement to release $>15 \mathrm{~m}^{3} \mathrm{~s}^{-1}$ of water for other users between Itezhitezhi and Kafue Gorge, including fisheries and wildlife. There is also a requirement to release a minimum flow of $25 \mathrm{~m}^{3} \mathrm{~s}^{-1}$ at all times, in addition to a minimum discharge of $300 \mathrm{~m}^{3} \mathrm{~s}^{-1}$ each day during a four-week period in March to mimic flooding conditions. Other water user allocations include the sugar estates $\left(10.7 \mathrm{~m}^{3} \mathrm{~s}^{-1}\right)$, municipal council $\left(4.06 \mathrm{~m}^{3} \mathrm{~s}^{-1}\right)$ and other agricultural entities $\left(1.38 \mathrm{~m}^{3} \mathrm{~s}^{-1}\right)$.

The development of the Kafue Gorge and Itezhi-tezhi dams has severely impacted the hydrology of the Kafue Flats (Kalumbaa \& Nyirendab 2017). Comparison of the inflows (based on Kafue Hook Bridge flow gauge) and outflows from Itezhi-tezhi suggest the timing of the annual flood cycle is maintained, but duration and amplitude of the wet season flows to the Flats are suppressed whilst dry season flows are enhanced (Figure 4). 


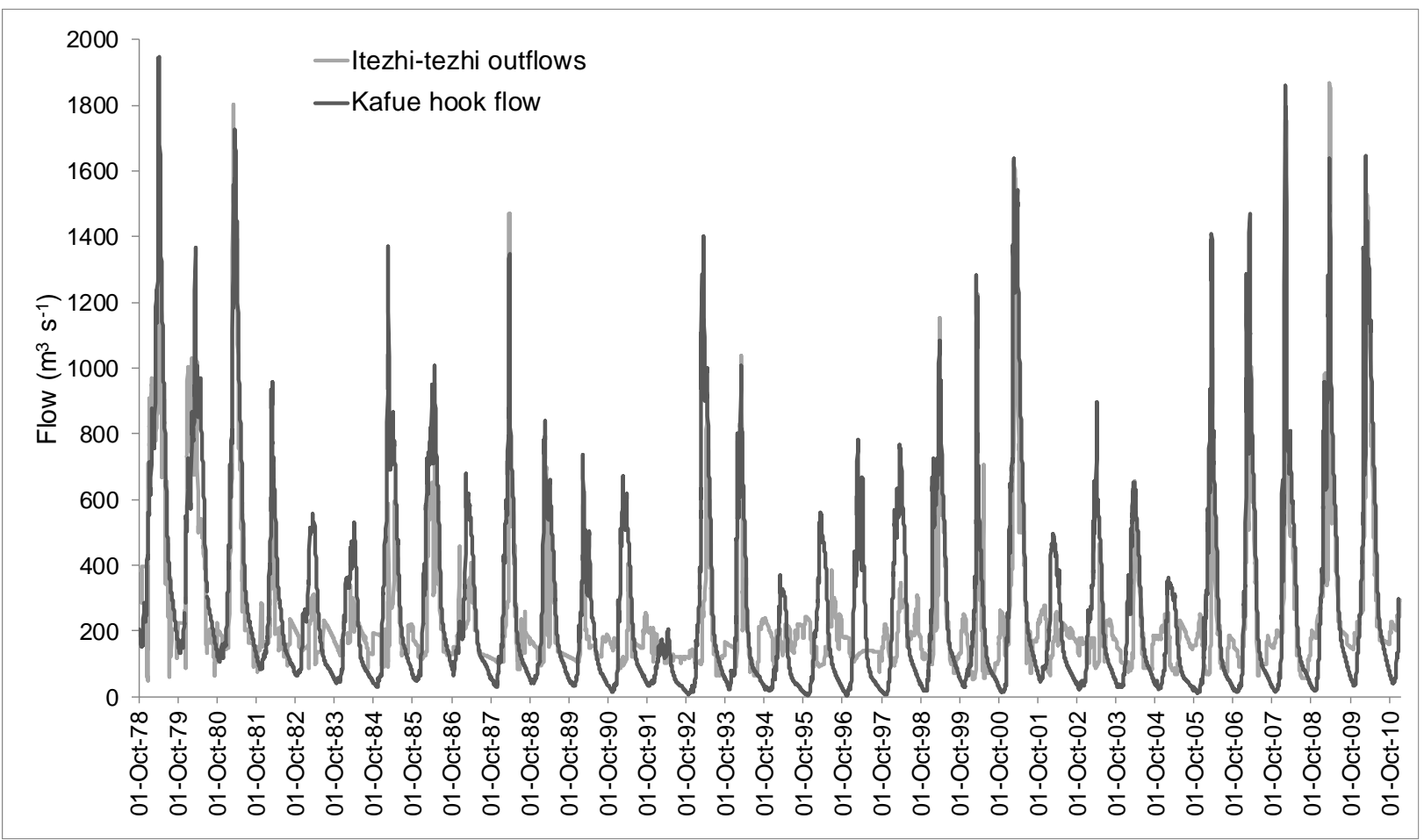

Figure 4. Hydrographs of natural inflow (Kafue Hook Bridge) and modified outflow from Itezhi-tezhi reservoir between October 1978 and December 2010. Note, peak flows are little affected but low flows are enhanced considerably

The flood release regime (i.e. minimum flow release of $300 \mathrm{~m}^{3} \mathrm{~s}^{-1}$ in March each year) stipulated by MEWD appears to have been designed to simulate the natural flooding regime and ensure a minimum flood, even in very dry years. However, it is not clear how this volume was chosen but is marginally less than the mean annual runoff of the catchment upstream of Itezhi-tezhi $(\approx 350$ $\left.\mathrm{m}^{3} \mathrm{~s}^{-1}\right)$. It is likely a nominal value was simply negotiated to ensure that some flooding occurs in all years because no formal environmental impact assessments were conducted in Zambia when Itezhi-tezhi and Kafue Gorge dams were built. Ironically, the mean March release between 1980 and 2010, equated to $496 \mathrm{~m}^{3} \mathrm{~s}^{-1}$. During this 30-year period, floods in excess of $300 \mathrm{~m}^{3} \mathrm{~s}^{-1}$ and $250 \mathrm{~m}^{3} \mathrm{~s}^{-1}$ were released in 17 years and 23 years, respectively. The four years (1990-1993) when March releases were below $250 \mathrm{~m}^{3} \mathrm{~s}^{-1}$, coincided with an extreme drought period in southern Africa when rainfall was only $10-25 \%$ of normal. During this period, flows in the Kafue were considerably below average and the natural flooding regime would have been much less than normal if not supplemented by releases from Itezhi-tezhi. Similar scenarios were experienced in 1995-1997 and 2002-2005.

Since completion of Itezhi-tezhi and Kafue Gorge dams, the flooding pattern within the Flats has been modified considerably as indicated above. As a consequence, the annual dry season wetted area has increased five-fold from about $300 \mathrm{~km}^{2}$ to $1500 \mathrm{~km}^{2}$ (CEH 2001) resulting in permanent lagoons forming where ephemeral aquatic habitats previously existed. By contrast, the maximum annual flooded area has been maintained, but the duration of peak flooding has 
been reduced because the period over which high discharges are maintained is shorter than before Itezhi-tezhi was built.

There are two major elements of concern associated with this change in hydrology of the Kafue Flats. The discharge regime has virtually eliminated the extreme low flows except during drought events. This is illustrated in the alteration of the mean monthly flow curves where the low flows typically experienced between July and November are virtually lost. There is now an acute lack of an annual period of prolonged low flows and the floodplain is inundated throughout the year. Consequently, there is a reduction in growth and contribution of terrestrial vegetation to the overall productivity of the floodplain, including grazing opportunities, and loss of shallow flooded grasslands on which the Kafue lechwe depend.

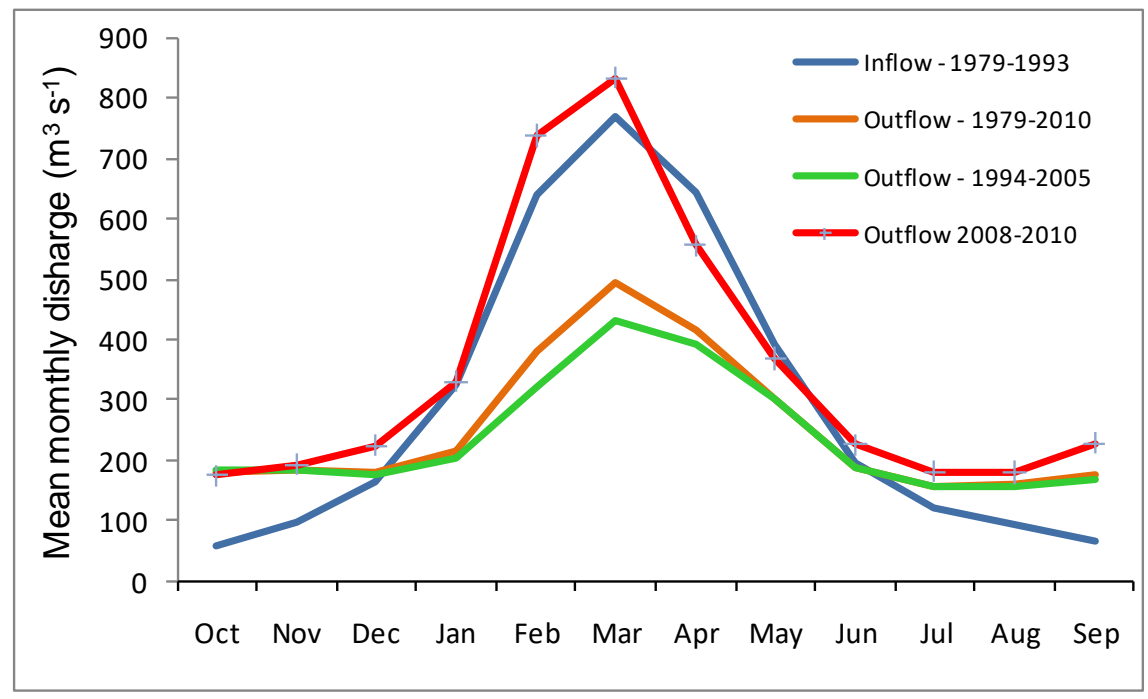

Figure 5. Alteration of the flooding cycle of the Kafue River, indicated by the difference in the inflow and outflow from Itezhi-tezhi reservoir between October 1979 and December 2010, including variations caused by further modifications between 2008 and 2010.

The second point of concern is the constant discharge from Itezhi-tezhi in recent years, which is maintained at approximately $200 \mathrm{~m}^{3} \mathrm{~s}^{-1}$ in the dry season, although peak wet season flows have not been modified (Figures 5 and 6 ). This scenario appears to be modification of flows to mimic a proposed hydropower discharge regime at Itezhi-tezhi. The proposal is to use Itezhitezhi dam for hydropower production based on a daily hydropeaking regime in which the flows will be ramped up from an overnight discharge of $20-25 \mathrm{~m}^{3} \mathrm{~s}^{-1}$ to a daytime rate of $315 \mathrm{~m}^{3} \mathrm{~s}^{-1}$ over a 20-30-minute period to meet peak demand over an 8-10 hour period during the day (Liechti et al. 2015). The hydropeaking proposal will result in a mean daily discharge of approximately $200 \mathrm{~m}^{3} \mathrm{~s}^{-1}$ and no low flow events, except perhaps during extreme droughts, and daily water level changes as extreme as $1.5 \mathrm{~m}$ in the floodplain downstream of the dam. This will have major ramifications for the fishing communities and ecosystem functioning, and would likely result in a collapse of the fishery along with destruction of the wetlands that the Kafue 
lechwe and numerous bird populations are dependent (Chansa \& Kampamba 2010). In addition, it is expected that the water level fluctuations could have serious implications for sugar cane production and fish farming in the Kafue Flats area.

A further issue arises at Itezhi-tezhi associated with the source of water in the reservoir for hydropower production. To maximize power production it is likely the outlet will be drawn from the bottom, deoxygenated waters resulting in discharge of water with low oxygen levels into the Kafue floodplain downstream of the dam. Some mechanism of alleviating this problem will be required if the fish stocks and other aquatic biota are not to suffer.

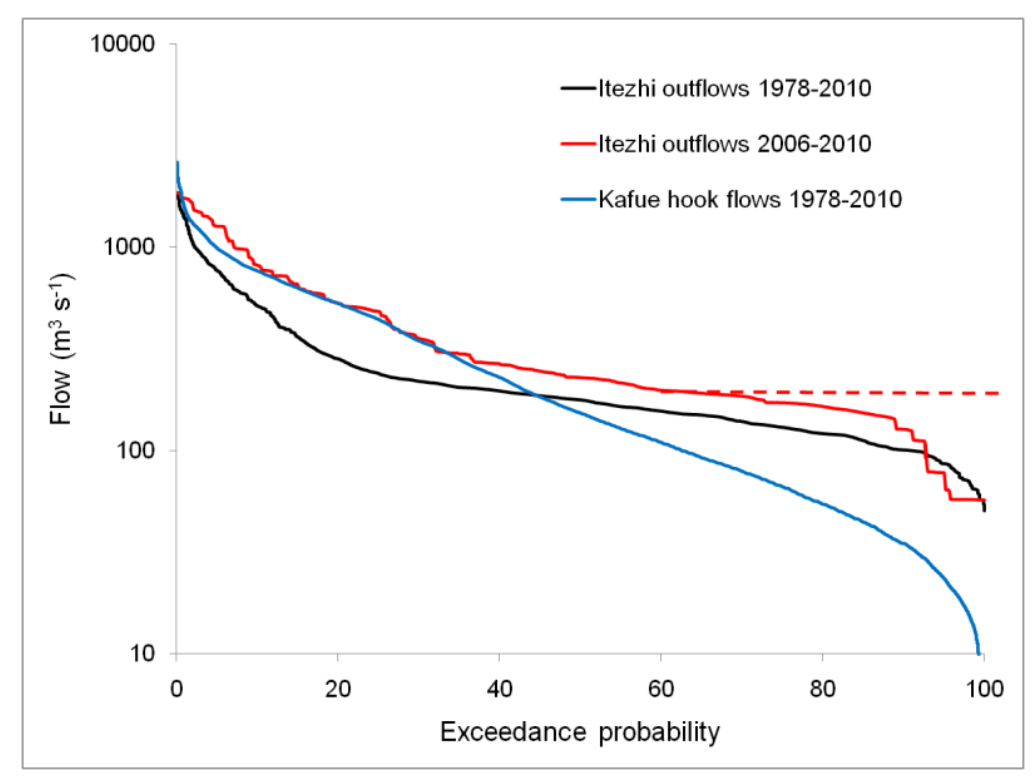

Figure 6. Flow exceedance curves for inflow and outflow from Itezhi-tezhi reservoir between October 1978 and December 2010, including variations caused by further modifications between 2008 and 2010 . The red dotted line indicates the modification to the curve if the proposed Itezhi-tezhi hydropower scheme becomes operational.

\section{Discussion}

Hydropower development and flow regulation have had both positive and negative impacts on the Kafue River downstream of Itezhi-tezhi (Mumba \& Thompson, 2005). The positive impacts are largely seen through improved electricity supply in Zambia, especially to the urban centres. The negative impacts are borne mostly by the rural communities whose livelihoods and food security depend on the services delivered by the Kafue river system, but there are also indirect impacts on wildlife and ecosystem functioning in the floodplain areas. It is important to reflect that Kafue Gorge dam was designed to conserve the Kafue Flats ecosystem as well as associated cultural and pastoral services (Chapman et al. 1971). The dam was designed to inundate a maximum area of $800 \mathrm{~km}^{2}$, and to work in tandem with Itezhi tezhi, which would 
provide the "live" storage and release of flow pulses through the Kafue Flats necessary to maintain continuous power production at the dam (CEH 2001). The biological importance of the flooding regime to the breeding behaviour of the floodplain fishes was also recognised, hence the need for the elevated flows in March each year to stimulate breeding. This is essentially an environmental flow regime to maintain ecosystem integrity in the floodplain ecosystem.

The construction of Itezhi-tezhi and Kafue Gorge dams has, however, changed the natural flooding pattern of the floodplain and resulted in disturbance of the wetland ecosystem (Schelle \& Pittock, 2005). These changes have affected the functioning and productivity of the wetland ecosystem, with knock-on effects on the livelihoods of rural people living on the Flats and those utilizing the floodplain resources (WWF, 2004; Knaap, 1994; Haller \& Merten, 2006).

Modification of the flow regime has negatively impacted on capacity to graze cattle. Dry season grazing in the eastern part of the Flats has been reduced considerably because of permanent inundation of grasslands, and opportunities in the western part of the Flats are compromised by increased desiccation and associated change in vegetation. This has resulted in increased competition over pastures because of reduced availability of grazing land and problems relating to displacement of traditional subsistence farmers, as well as increased poaching of wildlife because of its restricted distribution to a narrower belt of land between the dry land and flooded wetlands. Furthermore, outside protect areas/sanctuaries, wildlife is displaced by domestic stock and cropping.

Changes in species composition of fish catches in the Kafue Flats were noted as early as the late 1970s (Dudley \& Scully 1980), followed by a decline in riverine species in the earlier years following the closure of Itezhi-tezhi dam and predominance of lacustrine, eurytopic species as the ecosystem stabilised as a lake environment rather than the seasonally inundated floodplain of the past (Figure 3). This species change is currently undergoing further shifts, mainly as a result of proliferation of Nile tilapia throughout the Flats, but also more recently through the explosion of small meshed $(2.5 \mathrm{~cm})$ nets that are catching Brycinus lateralis and Tilapia sparrmanii and overexploiting the indigenous cichilds and invasive Nile tilapia (D. Tweddle pers. comm.).

The traditional fisheries of the Flats have also been affected by the dams, partly because of obstruction to longitudinal migration pathways along the river system (no fish passage facilities installed at the dams), but mostly through disruption of lateral connectivity onto the floodplain habitat where many of the fish species breed, resulting from the altered flooding regime (Deines et al. 2013). Fishing communities used to follow the patterns of flooding and water recession, and around October every year some fishing communities tended to shift several kilometres closer to the lagoons and river system from their permanent settlement because of 
the long distance between the fishing villages and where fishing activities are carried out. However, in recent years this has no longer happened because communities, especially around the Chunga Lagoon, have been permanently inundated. In addition, the continuous flooding regime has brought the fishing communities into greater and more continuous contact with hippopotami and crocodiles, and there is an increased prevalence of attacks in recent years.

The proposed hydropower development at Itezhi-tezhi will further modify the flow regime and potentially turn the floodplain into a more permanent lake ecosystem from a wetland based on fluctuating water levels associated with the flood pulse (Cowx et al. 2011; Deines et al. 2013). This will have serious impacts on the species living in the flooded wetland areas (e.g. Kafue lechwe, hippopotami and the diverse bird fauna) and fish species living in the main river channel, potentially turning the fishery into one dominated by lacustrine species, but also exacerbating the proliferation of invasive fish species to the detriment of the endemic Tilapiine species, as is already being observed (D. Tweddle pers. comm.).

A further impact of the change in flow regime by Itezhi-tezhi is the colonization and spread of grassland and woody species that are associated with dryland rather than wetland environments across the floodplain (e.g. Dichrostachys cinerea, Mimosa pigra, Acacia polycantha, Fiadherdia albida and Hypherrania sp.). In particular, the lack of periodic inundation has resulted in colonization by the thorny shrub Mimosa pigra, which is now covering large areas of the riparian zone around the Chunga lagoon and is encroaching into the littoral zone (Shanungu, 2009). This is restricting access to fishing grounds as well as smothering potential breeding areas for fish, especially the tilapia species.

Changes in the flooding regime have also impacted the Kafue lechwe population. Numbers of Kafue lechwe population have declined from more than 90,000 prior to construction of the dams to less than 40,000 in recent years (Chansa \& Kampamba 2010). Whilst much of this is attributable to poaching, the change in flooding patterns is also disrupting the distribution and breeding patterns of the species.

It is also highly likely that changes in aquatic ecology and ecosystem functioning linked to the alterations in hydrological regime will have impacted on the diverse water bird population distributions and possibly diversities. Unfortunately, inadequate monitoring and an absence of tourism has meant that evaluating trends in waterfowl populations, or birds in general, is limited.

To address the concerns raised about the proposed hydropower development at Itzehi-tzehi, stakeholders who would likely be affected by the highly modified flow regime, including Zambia Wildlife Authority and the Department of Fisheries, created community-based Natural Resources Management Boards (RMBs) to oversee the exploitation of natural resources to the 
benefit of the local communities (Nkhata \& Breen, 2010). They highlighted the importance and value of the key ecosystem services delivered by the Kafue Flats, including fisheries, wildlife (especially the globally important Kafue lechwe), sugar production, aquaculture and agriculture production, to Zesco in an effort to rationalise the power production regime at Itzehi-tezhi to benefit all natural resources. The aim was to regulate the flow regime to maintain the natural flood cycle and avoid the daily hydropeaking that would have destroyed the ecosystem as well as optimise the use of water to benefit the multiple stakeholders, as shown in Figure 7, and maintain the ecosystem services delivered from the floodplain (Acreman et al. 2000). To this end, the flow release regime from Itezhi-tezhi could be improved to the benefit of the rural communities on the Kafue Flats without significant loss to energy production based on the following considerations.

- As recommended by Acreman et al. (2000), the operating rules of Itezhi-tezhi and Kafue Gorge dams should be reviewed to determine if it is possible to modify them further to mitigate the negative environmental and social impacts. For example, more natural dry season conditions could be simulated by increasing the draw-down in the Kafue Gorge reservoir during the dry season, thus reducing the area of permanent inundation. This would require careful hydrological modelling and enhanced precision of flow releases from Itezhi-tezhi to ensure the water needed for power production at Kafue Gorge is available as required.

- The potential impact of development of hydropower at Itezhi-itezhi on the flooding regime and fisheries production is particularly concerning because the Kafue Flats could potentially be turned into a lake ecosystem from a seasonally flooded wetland system. This could result in further change in fisheries production as well as disruption of wildlife provision. It is essential that the ecosystem services analysis currently being carried out by WWF (and due for reporting in 2019; Loreen Katiyo, WWF, pers. comm), evaluates the financial impact and potential losses before the planning progresses beyond the point of no return. This will require DoF and ZAWA to establish full dialogue with Zesco at the earliest opportunity.

- Zesco should follow international guidelines on the ramping rate for water release from dams which is recommend no more than a $15 \mathrm{~cm}$ rise in water level per hour.

It is further recommended that an environmental flows study is conducted on the Kafue Flats, as initiated by World Wildlife Fund, to account for the ecosystem services provision of the region (Kalumbaa \& Nyirendab, 2017). 


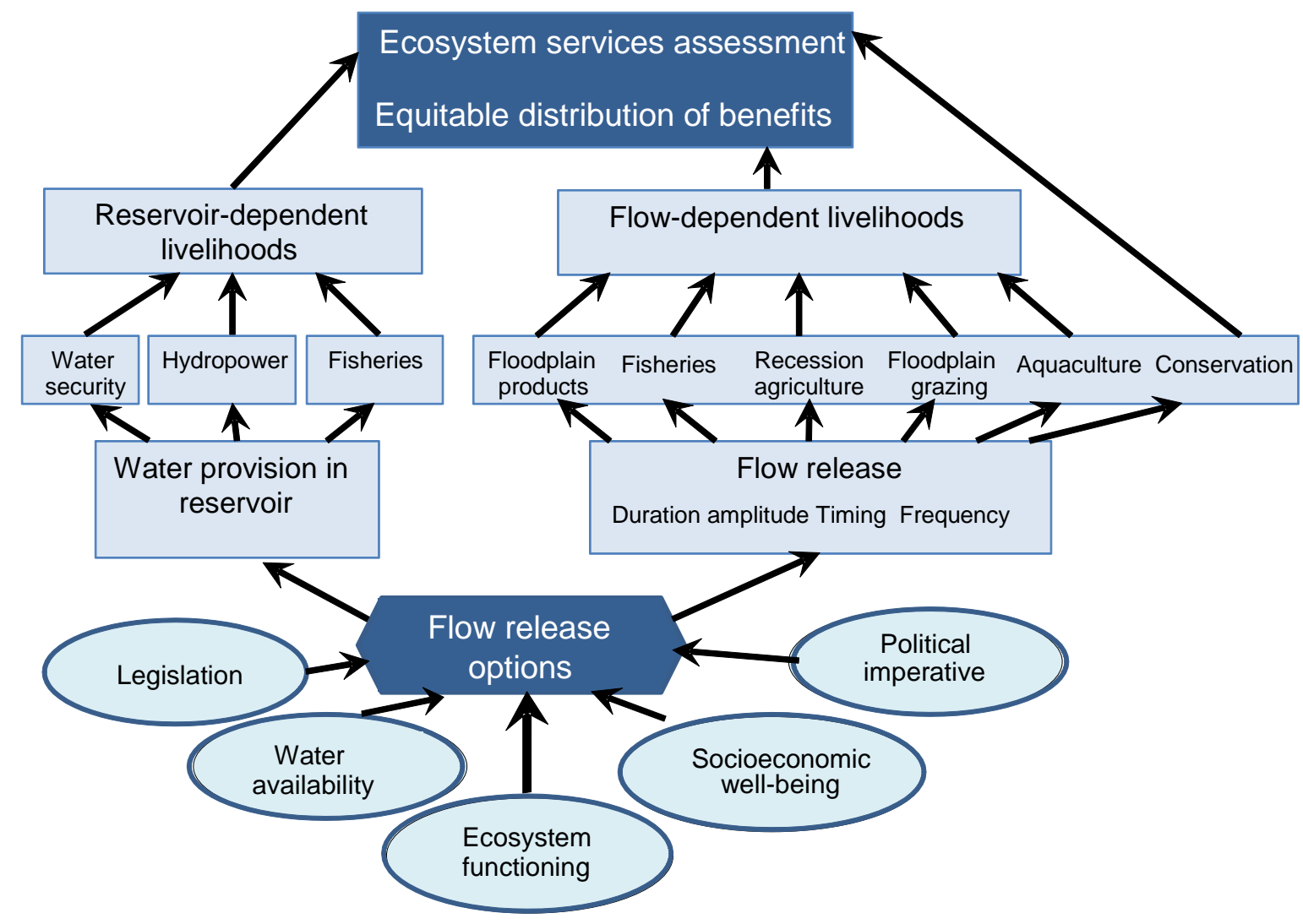

Figure 7. Flow chart showing optimization of water resource use for hydropower and other ecosystem services in the Kafue Flats( modified from Acreman 2000).

During this consultation, mobilising the key stakeholders through the RMBs will be pivotal in putting pressure on the power company to change its strategy (Haller \& Chabwela, 2009), although a positive outcome has yet to be realised. Further actions can also orientate around highlighting the impact of hydropower on loss of livelihoods and food and nutritional security, which could ultimately result in increased poverty and hunger, contrary to addressing the Sustainable Development Goals, especially SDG 1 alleviating poverty (Lynch et al. 20917). This is particularly important because poverty is widespread in Zambia, especially in rural communities such as those occupying the Kafue Flats floodplain. The problem of food security and poverty is expressed through dependency on fisheries and the lack of viable and sustainable livelihood options. Fishing communities suffer the threat of poverty and food security because of declining catches and floods that damage crops. Much of their food comes from the fishery and fish-dependent households have little or no alternative livelihoods. The population in the Kafue Flats floodplain is especially dependent on fish availability, and the seasonality of the activity implies vulnerability to food security during certain periods of the year. Consequently, it is likely that any adverse changes to the flooding dynamics with impact on rural livelihoods and food security of the communities dependent on the fisheries and wildlife resources in the region as well as disrupt recession agricultural practices. Unfortunately, there are few alternatives for the indigenous tribal people of the Flats so such a scenario will lead to considerable social disruption. 
Poverty and poor nutrition also affects the spread of HIV by altering sexual risk behaviour as women or female-headed households lacking adequate food for their families are more likely to engage in risky activities, such as exchanging sex for food, fish or money (Merten. \& Haller, 2007). These women are less likely to protect themselves from the disease due to their perceived low status. While HIV is a symptom, poverty is the cause and failure to cope and contain the situation, increasingly forces some food insecure households to trade in illicit activities such as prostitution and fish for sex as a coping strategy, while fishers engage in illegal fishing and fishing using unsustainable methods (Kissling et al. 2005). Since fish provide the micro-nutrients and proteins necessary for good health, they form an important component in the response to HIV because HIV and nutrition are strongly linked.

In conclusion, optimizing hydropower development in the Kafue to ensure continued delivery of the ecosystem services provided is essential for meeting social and economic outcomes defined under international policy frameworks.

\section{Acknowledgements}

The authors declare no conflicts of interest.

The research was carried out under the EU ACPII project Elaboration of a management plan for the Kafue Flats fishery (Ref: CU/PE1/MZ/10/002).

\section{References}

Acreman, M.C., Farquharson, F.A.K., McCartney, M.P. Sullivan, C., Campbell, K., Hodgson, N., Morton, J., Smith, D., Birley, M., Knott, D., Lazenby, J., Wingfield, R. \& Barbier, E.B. (2000) Managed flood releases from the Itezhi-tezhi Reservoir: summary report. Guidelines for artificial flood releases from reservoirs to restore and maintain downstream wetland ecosystems and their dependent livelihoods: Final Report to DFID, Centre for Ecology and Hydrology, Wallingford, UK

Béné, C. \& Friend, R.M., (2009) Water, poverty and inland fisheries: lessons from Africa and Asia. Water International 34, 47-61.

Béné, C., Hersoug, B. \& Allison, E.H. (2010) Not by rent alone: analyzing the pro-poor functions of small-scale fisheries in developing countries. Development Policy Review 28, 325-358.

Béné, C., Arthur, R., Norbury, H., Allison, E.H., Beveridge, M., Bush, S., Campling, L., Leschen, W., Little, D., Squires, D., Thilsted, S.H., Troell, M. \& Williams, M. (2016) Contribution of fisheries and aquaculture to food security and poverty 
reduction: assessing the current evidence. World Development 79, 177-196.

Central Statistical Office (2011) Preliminary Report 2010 Census of Population and Housing, CSO: Lusaka.

Central Statistical Office and Department of Fisheries (2007) 2006 Fishery Frame Survey Report, CSO Zambia, 99 pp.

Centre for Ecology and Hydrology (2001). Managed Flood Releases: A working conference on guidelines for managed flood releases and lessons learned from Itezhi-tezhi. Lusaka 13-14 March 2001. Workshop Report.

Chansa, W, \& Kampamba, G. (2010). The population status of the Kafue Lechwe in the Kafue Flats, Zambia. African Journal of Ecology 48, 837-840.

Chapman, D.W., Dudley, R.G., Miller, W.H. and Scully, R.J. (1971). Ecology of fishes in the Kafue River. Technical report 2. The University of Idaho, Moscow, 66 pp.

Cowx, I.G., Lungu, A. \& Mills, A. (2011) Elaboration of a management plan for the Kafue Flats fishery, Zambia; EU ACPII, CU/PE1/MZ/10/002, 87 pp.

Deines, A.M., Bee, C.A., Katongo, C., Jensen, R. \& Lodge, D. (2013). The potential trade-off between artisanal fisheries production and hydroelectricity generation on the Kafue River, Zambia. 58, 640-654.

Dudley, R.G. \& Scully, R.J. (1980). Changes in experimental gillnet catches from the Kafue Floodplain, Zambia, since construction of the Kafue Gorge Dam. Journal of Fish Biology $16,521-535$.

Fluet-Chouinard, E., Funge-Smith, S. \& Mclntyre, P.B. (2018). Global hidden harvest of freshwater fish revealed by household surveys. Proceedings of the National Academy of Sciences 1721097115.

Haller, T. \& Merten, S. (2006) 'No capital needed!' De facto open access to Common Pool Resources, Poverty and Conservation in the Kafue Flats, Zambia. Policy Matters 14, 103-113.

Haller, T. \& Chabwela, H.N. (2009). Managing common pool resources in the Kafue Flats, Zambia: from common property to open access and privatisation. Development Southern Africa 26, 555-567.

Kalumbaa, M. \& Nyirendab E. (2017). River flow availability for environmental flow allocation downstream of hydropower facilities in the Kafue Basin of Zambia. Physics and Chemistry of the Earth, Parts A/B/C 102, 21-30.

Kissling, E., Alison, E.H., Seeley, J.A., Russell, S., Bachmann, M., Musgrave, S.D., Heck, S. (2005). Fisherfolk are among those most at risk to HIV: A Cross-country comparison of estimated prevalence and numbers infected among groups at risk. AIDS 19,1939-1946.

Knapp, M. (1994) Status of fish stocks and fisheries of thirteen medium-sized African reservoirs. CIFA Technical Paper 26. FAO, Rome. 
Liechti, T.C., Matos, J.P., Boillat, J.-L. \& Schleis, A.J. (2015) Influence of hydropower development on flow regime in the Zambezi River Basin for different scenarios of environmental flows. Water Resource Management 29, 731-747.

Lynch, A.J., Cowx I.G., Fluet-Chouinard E., Glaser S.M., Phang S.C., Beard T.D., Jr.,. ... Youn S. (2017). Inland fisheries - invisible but integral to the UN Sustainable Development Agenda for ending poverty by 2030. Global Environmental Change. 47, 167-173.

Merten, S. \& Haller, T. (2007). Culture, changing livelihoods, and HIV/AIDS discourse:

Reframing the institutionalization of fish-for-sex exchange in the Zambian Kafue Flats. Culture Health \& Sexuality 9, 69-83.

Mumba, M., Thompson, J.R. (2005). Hydrological and ecological impacts of dams on the Kafue Flats floodplain system, southern Zambia. Physics and Chemistry of the Earth $\mathbf{3 0}$, $442 \mathrm{e} 447$.

Musumali, M.M., Heck, S., Husken, S.M.C. \& Wishart, M. (2009) Fisheries in Zambia: An undervalued contributor to Poverty Reduction. The WorldFish Center/The World Bank. Policy Brief 1913.

Nkhata, B. \& Breen, C.M. (2010). Performance of community-based natural resource governance for the Kafue Flats (Zambia). Environmental Conservation 37, 296-302.

Nyimbili, B. (2006). An evaluation in fish Population Changes In the Kafue flats floodplain of Zambia-Zambia. MSc thesis University of Bergen, Norway

Schelle, P. \& Pittock, J. (2005). Restoring the Kafue Flats: a Partnership Approach to Environmental Flows in Zambia, Dams Initiative. Global Freshwater Programme WWF International Panda House, Weyside Park, Godalming.

Schwanck, E.J. (1995). The introduced Oreochromis niloticus is spreading on the Kafue floodplain, Zambia. Hydrobiologia 315, 143-147

Seyam, I.M., Hoekstra, A.Y., Ngabirano, G.S. \& Savenije, H.H.G. (2001). the value of freshwater wetlands in the Zambezi basin. Globalization and water resources management: the changing value of water. AWRA/IWLRI Conference, University of Dundee 6-8 August 2001.

Shanungu, G.K. (2009). Management of the invasive Mimosa pigra L. in Lochinvar National Park, Zambia. Biodiversity (Ottawa) 10, 56-60.

Shanungu, G.K., Kaumba, C.H. \& Beilfuss, R. (2015). Current Population Status and Distribution of Large Herbivores and Floodplain Birds of the Kafue Flats Wetlands, Zambia: Results of the 2015 Wet Season Aerial Survey. Zambia Wildlife Authority, Chilanga, Zambia.

World Fish Centre (2004) Proceedings of the International Workshop on the Fisheries of the Zambezi Basin. Report for Workshop, Livingstone, Zambia, 31 May-2 June, 2004.

World Wide Fund for Nature (2006) Zambia - Kafue Flats www.panda.org/about wwf/where we work/africa/where/zambia/kafue/index.cfm. 
World Wildlife Fund (WWF) (2004) Study report on the role of the Kafue Flats fishery in sustaining the socio-economic livelihoods of the local communities. Kafue River Basin Dialogue on Water, Food and Environment Project. WWF Zambia / University of Zambia (UNZA). 